\title{
THE PREVALENCE AND CLINICAL CHARACTERISTICS OF PRIMARY HEADACHE IN IRRITABLE BOWEL SYNDROME: a subgroup of the functional somatic syndromes
}

\author{
Rosa LS SOARES'1, Pedro Ferreira MOREIRA-FILHO', \\ Carolina Possidente MANESCHY2, Julia Fumian BREIJÃO² \\ and Nathan Mielke SCHMIDTE ${ }^{2}$
}

\begin{abstract}
Context - The irritable bowel syndrome and primary headache are two chronic diseases characterized by symptoms of recurring pain and affect approximately $10 \%-20 \%$ of the general population. Objectives - To study the prevalence of primary headache in volunteers with irritable bowel syndrome in a Brazilian urban community. Methods - It was evaluated the prevalence of primary headache associated with irritable bowel syndrome in adult volunteers 330 no patients. The protocol included the Rome III criteria, international classification of Headaches, later divided into four groups: I- Irritable bowel syndrome $(\mathrm{n}=52)$, II- Primary headache ( $\mathrm{n}=45)$, III-Irritable bowel syndrome $(\mathrm{n}=26)$ and headache, and IV-Controls $(207)$. Results - We not found significant difference in the average age of the four groups and the diagnosis of irritable bowel syndrome, primary headache and their association was more frequent in females. The frequent use of analgesics was greater in groups II and III. Conclusion - Our results suggest that irritable bowel syndrome and primary headache are also common in third world countries. The frequency in use of analgesics in association between the two entities was relevant. The identification of irritable bowel syndrome patients with different clinical sub-types could improve the therapeutics options and the prevention strategies.
\end{abstract}

HEADINGS - Irritable bowel syndrome. Headache. Comorbidities.

\section{INTRODUCTION}

The functional gastrointestinal disorders (FGIDs) are a heterogeneous group of chronic conditions that are considered important to public health because they are remarkably common, can be disabling, and induce a major social and economic burden ${ }^{(12,16,24,26,27,29,31,34)}$. The clinical severity is probably influenced by the presence of intestinal and extra-intestinal symptoms and the definition of clinical severity remains the key to better understanding of the public health impact of FGIDs $^{(6,22,41)}$. The comorbidities are correlated with enhanced medical help seeking, worse prognosis, all resulting in a reduced quality of life.IBS affects $15 \%$ of the general population and is the most common reason for patients and generalists to consult gastroenterologists ${ }^{(6,41)}$. Comorbidity with other functional gastrointestinal disorders is high and may be caused by shared pathophysiological mechanisms such as vis- ceral hypersensitivity ${ }^{(41)}$. Psychiatric disorders, especially major depression, anxiety, and somatoform disorders, occur frequently. The nongastrointestinal nonpsychiatric disorders with the best documented association are fibromyalgia, chronic fatigue syndrome, temporomandibular joint disorder and chronic pelvic pain $^{(1,5,20)}$. In addition, IBS is often accompanied by other extra-intestinal symptoms, as asthma and cerebral pain symptoms as primary headache ${ }^{(39)}$. Chronic headache was reported by $34 \%-50 \%$ of IBS patients in three controlled demographical studies, which is significantly higher compared to healthy subjects. The high prevalence of comorbidities in IBS patients has led investigators to develop hypothesis regarding underlying pathophysiologic mechanisms linking these disorders $^{(1,19,25,36,41)}$. Possibles common pathogenetic mechanisms of IBS and migraine consider the role of brain-gut axis, as well as neuroimmune and neuroendocrine interactions ${ }^{(3,18-30)}$. Serotonin as a major

Declared conflict of interest of all authors: none

Departamento de Medicina Interna, Faculdade de Medicina, Universidade Federal Fluminense (UFF), Niterói, RJ, Brasil; ${ }^{2}$ Hospital Antonio Pedro, Faculdade de Medicina, Universidade Federal Fluminense (UFF), Niterói, RJ, Brasil

Supported by: Conselho Nacional de Desenvolvimento Científico e Tecnológico (CNPq-Brasil)

Correspondence: Rosa LS Soares. Departamento de Medicina Interna, Faculdade de Medicina, Universidade Federal Fluminense. Rua Marques do Paraná 189 /1002 Araruama - 24030-210 - RJ, Brasil. E-mail: rosaleonora@.gmail.com 
neurotransmitter of the gastrointestinal tract plays a relevant role in the IBS ${ }^{(4,10,36)}$. Today IBS is viewed upon a disorder of dysregulation of the so called brain-gut axis and lines of evidence also suggest that inflammation of the gastrointestinal tract may be of great importance in the majority of subgroups of IBS patients. Studies of comorbidities are of great scientific interest. They can contribute to the definition of new pathogenetic hypothesis to be tested experimentally $y^{(8,22,23,31)}$. To knowledge and assessment of comorbidities somatic symptoms in IBS patients might allow to identify sub-groups of IBS patients with special characteristics and lead to adaptation of therapeutic concept $t^{(5,39)}$.

To study the prevalence of PH in volunteers with IBS in a Brazilian urban community.

\section{METHODS}

This study was conducted with 330 volunteers (177 women and 173 men residents in Niteroi - RJ - Brazil) during a 2 years period from January 2006 to January 2008, and was approved by local ethical committee number CAE 0109025800007 and by our institutional review board (IRB) at Faculty of Medicine. The volunteers were selected from students and employees of the Faculty of Medicine, Fluminense Federal University, Niterói, RJ, Brazil, recruited through a poster affixed on the door of the group of study of intestinal diseases (outpatients unit), University Hospital Antonio Pedro (HUAP). This approach was used in order to obtain a population sample that would not consist of ambulatory or hospital patients, but that would represent the population in general. The inclusion criteria were age above 18 years and volunteers from the general population. The exclusion criterium included the following: the diagnostic suspicion of organic disease of the gastrointestinal tract. (including positives stool examination for ova and parasites) and if the volunteers were unable to complete the questionnaire. All participants were provided with an IRB-approved information sheet that described the purpose of the study, voluntary nature of the study, study aims, methods, and population, and were given opportunity to ask questions. The volunteers were evaluated in outpatients clinic for FGD at HUAP. After obtaining informed consent, the volunteers were submitted to a complete clinical evaluation, completed a questionnaire which included Rome III ${ }^{(9)}$ criteria for IBS (recurrent abdominal pain or discomfort at least 3 days per month in the last 3 months associated with 2 or more of the following: 1. Improvement with defecation. Onset associated with a change in frequency of stool; 2 . Onset associ- ated with a change in form (appearance) of stool Criteria fulfilled for the last 3 months with symptom onset at least 6 months prior to diagnosis. Discomfort means an uncomfortable sensation not described as pain). The diagnosis of HP was defined by the second International Classification of Headache Disorders (ICHD-II) ${ }^{(15,21)}$ criteria diagnosis and the average monthly headache frequency over the prior 3 months (either $<15$ days, or $\geq 15$ days) and the frequency of analgesic use. A total of 330 volunteers completed the surveys. The exclusion criteria included the following: the diagnostic suspicion of organic disease of the gastrointestinal tract. (including positives stool examination for ova and parasites). Twenty volunteers were excluded because presented the diagnostic suspicion of organic disease of the gastrointestinal tract (including positives stool examination for ova and parasites).

\section{Statistical Analysis}

Analysis of categorical data was done using $\chi 2$ or Fisher's exact test and continuous data were analyzed using independent sample $t$-test. For data with deviation from normality Odds ratios (OR) with $95 \%$ confidence intervals (CI), were used to measure the associations between the comorbid conditions and the groups. All statistical hypotheses were tested at 0.05 level of significance, and $P<0.05$ was considered significant. The analysis was performed using SAS version 9.1 (SAS Institute, Inc., Cary, NC, USA).

\section{RESULTS}

After evaluation we identified four groups: IBS Group I $(\mathrm{n}=52,15,7 \%$, mean age 27,6+/- 8,7 years, 40 female and 12 male); HP Group II ( $\mathrm{n}=45,13,6 \%$, mean age $34,6+/-8,9$ years, 29 female and 16 male), IBS associated HP Group III $(\mathrm{n}=26-7,8 \%$, mean age $34,4+/-13$ years, 22 female and 4 male) and normal controls Group IV $(n=207,62,7 \%, 87$ female and 120 male). The prevalence of IBS was $19,3 \%$ in total and $33,3 \%$ of IBS volunteers reported chronic headache. There was no significant difference in the mean age between the three groups when we compared with control group $(P>0,05)$. IBS and PH were most frequent among females when we compared with the control group $(P<0,05)$. The frequency of analgesic use (more than four times a month) was similar in volunteers with PH (GII-16 and GIII-12, $P>0,05$, OR-1,55, $95 \%$ CI- $0,58-4,15)$, and significantly higher when we compared with another two groups (GI-4 $P<0,01$, OR- $0,15,95 \%$ CI- $0,04-0,49)$ and G IV-10 $P<0,01$, OR-0,09, 95\% CI-0,04-0,23) studied (Table 1).

TABLE 1. Prevalence of female and frequency of the analgesic use in the four groups ( $\%)(\mathrm{n}=330$ volunteers)

\begin{tabular}{|c|c|c|c|c|c|c|c|c|}
\hline & \multicolumn{2}{|c|}{$\begin{array}{c}\text { GI/IBS } \\
52(15,7 \%)\end{array}$} & \multicolumn{2}{|c|}{$\begin{array}{c}\text { GII/PH } \\
45(13,6 \%)\end{array}$} & \multicolumn{2}{|c|}{$\begin{array}{c}\text { GIII/IBS + PH } \\
26(7,8 \%)\end{array}$} & \multicolumn{2}{|c|}{$\begin{array}{c}\text { GIV/controls } \\
207(62,7 \%)\end{array}$} \\
\hline & $\mathrm{n}$ & $\%$ & $\mathrm{n}$ & $\%$ & $\mathrm{n}$ & $\%$ & $\mathrm{n}$ & $\%$ \\
\hline Female & $* 40$ & (77) & $* 29$ & (64) & $* 22$ & $(84.6)$ & 87 & $(42)$ \\
\hline Analgesic use & 4 & $(7.6)$ & $* * 16$ & $(35.5)$ & $* * 12$ & (46.1) & 10 & $(4.8)$ \\
\hline
\end{tabular}

GI/IBS: group I/Irritable bowel syndrome; GII/IBS: group II/Primary Headache; GIII/IBS+PH: group III and IBS-group III/Primary Headache; GIV-controls. *-P<0,05 compared with controls; $* *-P<0,01$ when compared GII and GIII with GI and GIV 


\section{DISCUSSION}

In the present study, a original brazilian investigation, the prevalence of symptoms consistent with IBS and HP, female predominance and mean age were similar to the reported in the literature. We selected volunteers non-patients because the case controls studies can lead to an overestimation of comorbitiy and metodological bias. These facts can be attributed to different patients clinical conditions in primary, secondary and tertiary care, and different definitions of diseases, as well as diverse classification of patients sub-groups. Our data demonstrated that the percentage of diagnosis of IBS and $\mathrm{PH}$ is in agreement of another studies. IBS affects 15\%-23\% of the general population and is the most common reason for patients and generalists to consult gastroenterologists In addition, our data showed that the percentage of IBS diagnosis and $\mathrm{PH}$ is in accordance with other studies. IBS affects $15 \%-23 \%$ of the general population and is the most common reason for patients and general practitioners to consult gastroenterologists ${ }^{(6,}$ $20,26,29,31,39,42$. Globally, the percentage of adult population with an active headache disorder is $47 \%$. In controlled demographical studies chronic headache was reported by $34 \%-50 \%$ of IBS patients, and many authors reported that headache suffers are predisposed to gastrointestinal complaints ${ }^{(1,3,18,19,24,30,36,41)}$. These findings has led investigators to develop hypotesis regarding underlying pathophysiologics mechanisms connecting these disorders. Today IBS is viewed upon a disorder of dysregulation of the so called brain-gut axis ${ }^{(8,10,30,32,33,38)}$.

Comorbidities or extra-intestinal symptoms are frequently in a sub-type of IBS patients. The best documented nonpsychiatric extra-intestinal comorbidites are fybromialgia, chronic fatigue syndrome and chronic pelvic pain. However, IBS is also often accompanied by another extra-intestinal symptoms, as asthma and cerebral pain symptoms as primary headache. The pathophysiology mechanisms suggest that IBS patients with one or more somatic comorbitdities might represent a separate sub-group ${ }^{(6,17,20,29,39,42)}$.
We also found that the number of female volunteers with diagnosis of IBS and PH was significantly higher than male volunteers. Gender differences in IBS and PH are well established. However the exact role of gender remains to be determined. The present results suggest that IBS and CP appear to be equally common in the Third World, and we suggest that IBS and PH can be considered two transcultural functional disorders ${ }^{(14,17,35,37)}$.

No clinical differences were also noted among patients with $\mathrm{PH}$ without irritable bowel syndrome, and those with both conditions. The exception was the higher percentage of the frequency of analgesic medication use in $\mathrm{PH}$ volunteers when we compared the four groups studied. The association between the presence of headache and the frequently use of analgesics in our study might lead to more clinical exposition to analgesics abuse complications in the IBS patients with headache associated. Recent studies confirmed that medication overuse headache is a biobehavioral disease. These patients are difficult to treat and have a poor quality of life and great tendency to chronification $^{(7,13,14,17,37,40)}$.

The presence of somatic comorbidities in IBS patients account for up to $3 / 4$ of excess health care visits and is correlated with,worse prognosis, and higher rates of anxiety and depression-all resulting in a reduced quality of life. The clinical severity is probably influenced by the intestinal and extra-intestinal symptom burden ${ }^{(2,11,42)}$.

\section{CONCLUSIONS}

This study provides valuable information about clinical and epidemiological aspects of IBS in Brazil. Our results suggest that the identification of IBS patients with different clinical sub-types could improve the therapeutics options and the prevention strategies. We believe also that studies of comorbidity in IBS can contribute to the definition of new pathogenic hypothesis to be tested experimental.

Soares RLS, Moreira Filho PF, Maneschy CP, Breijão JF, Schmidte NM. Prevalência e características clínicas da cefaleia primária na síndrome do intestino irritável: um sub-grupo de síndromes somáticas funcionais. Arq Gastroenterol. 2013,50(4):281-4.

RESUMO - Contexto - A síndrome do intestino irritável e a cefaleia primária são duas doenças crônicas caracterizadas por sintomas de dor recorrente e afetam aproximadamente 10\%-20\% da população em geral. Objetivo - Estudar a prevalência da síndrome do intestino irritável associada a cefaleia primária em voluntários, em uma comunidade urbana do Brasil. Métodos - Foi avaliada a prevalência de cefaleia primária associada a sindrome do intestino irritável em 330 voluntários adultos não pacientes. O protocolo incluiu Critérios de Roma III, Classificação Internacional de Cefaleias, posteriormente divididos em quatro grupos: I- Síndrome do Intestino Irritável $(\mathrm{n}=52)$, II- Cefaleia Primária $(\mathrm{n}=45)$, III- Síndrome do Intestino Irritável, Cefaleia ( $\mathrm{n}=26$ ) e IV- Controles (207). Resultados - Não houve diferença significativa na idade média dos quatro grupos e o diagnóstico da síndrome do intestino irritável, cefaleia primária e sua associação foi mais freqüente no sexo feminino. A utilização freqüente de analgésicos foi maior nos grupos II e III. Conclusão - Nossos resultados sugerem que a síndrome do intestino irritável e a cefaleia primária são comuns também em países do terceiro mundo. A frequência no uso de analgésicos na associação entre as duas entidades foi relevante, o que permite identificar subgrupos de pacientes com síndrome do intestino irritável conduzindo a adaptações na condução terapêutica.

DESCRITORES - Síndrome do intestino irritável. Cefaleia. Comorbidades. 


\section{REFERENCES}

1. Aamodt AH, Stovner LJ, Hagen K, Zwart JA. Comorbidity of Headache and gastrointestinal complaints. The Head-Hunt study. Cephalagia. 2008;28:144-151.

2. Andrasik F, Grazzi L, Usai S, Buse DC, Berson G. Non-pharmacology approaches to treating chronic migraine with medication overuse. Neurol Sci. 2009;30:S89-93.

3. Barbara G, De Giorgio R, Stranghellini V, Cremon C, Salvioli B,Corinaldesi R. New pathophysiological mechanisms in irritable bowel syndrome. Aliment Pharmacol Ther. 2004;20:1-9.

4. Bigal ME, Lipton RB. The epidemiology, burden, and comorbidities of migraine Neurol Clin. 2009;27:321-34.

5. Bonavita $\mathrm{V}$, De Simone R. Towards a definition of comorbidity in the light of clinical complexity. Neurol Sci. 2008;29:S99-S102.

6. Breckan RK, Asfeldt AM, Straume B, Florholmen J, Paulssen EJ. Prevalence, comorbidity, and risk factors for functional bowel symptoms: a population-based survey in Northern Norway. Scand J Gastroenterol. 2012;47:1274-82.

7. Camilleri M. Treating irritable bowel syndrome: overview,perspective and future therapies. Br J Pharmacol. 2004;141:1237-48.

8. Downing JE, Miyan JA. Neural immunoregulation: emerging roles for nerves in immune homoestasis and disease. Immunol Today. 2000;21:281-9.

9. Drossman DA. The functional gastrointestinal disorders and the Rome III process Gastroenterology. 2006;130:1377-90.

10. Färber L, Haus U, Späth M, Drechsler S. Physiology and pathophysiology of the 5-HT3 receptor. Scand J Rheumatol Suppl. 2006;119:2-8

11. Gracia-Naya M, Sánchez-Valiente S, Latorre-Jiménez AM, Ríos-Gómez C, Santos-Lasaosa S, Mauri-Llerda JA, García-Gomara MJ. Patients with Headache and medication abuse. Indications of response to ambulatory treatment. Rey Neurol. 2009:49:225-30.

12. Gralnek IM, Hays RD, Kilbourne A, Naliboff B, Mayer E. The impact of irritable bowel syndrome on health-related quality of life.Gastroenterology. 2000;119:655-60.

13. Grazzi L, Usai S, Prunesti A, Bersone G, Andrasik F. Behavioral plus pharmacological treatment versus pharmacological treatment only for chronic migraine with medication overuse after day-hospital withdrawal. Neurol Sci. 2009;30:S117-9.

14. Gupta S, McCarson KE, Welch KM, Berman NE. Mechanisms of pain modulation by sex hormones in migraine. Headache. 2011;51:905-22.

15. Hagen K, Zwart JA, Vatten L, Stovner LJ, Bovim G. Head-HUNT: validity and reliability of a headache questionnaire in a large population-based study in Norway. Cephalalgia. 2000;20:244-251.

16. Halder SL, Locke GR 3rd, Schleck CD, Zinsmeister AR, Melton LJ 3rd, Talley NJ. Natural history of functional gastrointestinal disorders: a 12-year longitudinal population-based study. Gastroenterology. 2007;133:799-807.

17. Headache Classification Subcommittee of the International Headache Society. The international classification of headache disorders: 2 nd edition. Cephalalgia. 2004;24 (Suppl 1):9-160.

18. Kanaan RA, Lepine JP, Wessely SC. The association or otherwise of the functional somatic syndromes. Psychosom Med. 2007;69:855-9.

19. Kurth T, Holtmann G, Neufang-Hüber J, Gerken G,Diener HC. Prevalence of unexplained upper abdominalsymptoms in patients with migraine. Cephalalgia. 2006;26:506-10.

20. Lackner JM, Ma CX, Keefer L, Brenner DM, Gudleski GD, Satchidanand N, Firth R, Sitrin MD, Katz L, Krasner SS, Ballou SK, Naliboff BD, Mayer EA. Type, Rather Than Number, of Mental and Physical Comorbidities Increases the Severity of Symptoms in Patients With Irritable Bowel Syndrome. Clin Gastroenterol Hepatol. 2013. doi: 10.1016/j.cgh.2013.03.011.
21. Lipton RB, Bigal ME, Steiner TJ, Silberstein SD, Olesen J AR. Classification of Primary Headaches. Neurology. 2004;63:427-35.

22. Locke GR 3rd, Zinsmeister AR, Fett SL, Melton LJ 3rd, Talley NJ. Overlap of gastrointestinal symptom complexes in a US community. Neurogastroenterol Motil. 2005;17:29-34

23. Mach T. The brain-gut axis in irritable bowel syndrome--clinical aspects. Med Sci Monit. 2004;10:RA125-31.

24. Maxion-Bergemann S, Thielecke F, Abel F, Bergemann R. Costs of irritable bowel syndrome in the UK and US. Pharmacoeconomics. 2006;24:21-37.

25. Meucci G, Radaelli F, Prada A, Bortoli A, Crotta S, Cerrato C, Minoli G. Increased prevalence of migraine in patients with uninvestigated dyspepsia referred for open access upper gastrointestinal endoscopy. Endoscopy. 2005;37:622-5.

26. Minocha A, Johnson WD, Abell TL, Wigington WC. Prevalence, sociodemography, and quality of life of older versus younger patients with irritable bowe syndrome: a population-based study. Dig Dis Sci. 2006;51:446-53.

27. Quigley EM, Bytzer P, Jones R, Mearin F. Irritable bowel syndrome: the burden and unmet needs in Europe. Dig Liver Dis. 2006;38:717-23.

28. Riedel A, Schmidtmann M, Stengel A, Goebel M, Wisser AS, Klapp BF, Mönnikes H. Somatic comorbidities of irritable bowel syndrome: a systematic analysis Journal of Psychosomatic Research. 2008;64:573-582.

29. Saito YA, Schoenfeld P, Locke GR 3rd. The epidemiology of irritable bowel syndrome in North America: a systematic review. Am J Gastroenterol. 2002;97:1910-5.

30. Sánchez del Río-González M. Chronic migraine: pathophysiology. Rev Neurol. 2012;54:S13-9 65 .

31. Soares RL, dos Santos JM, Rocha VR. Prevalence of irritable bowel syndrome in a Brazilian Amazon community. Neurogastroenterol Motil. 2005;17:883.

32. Tack J, Broekaert D, Fischler B, Van Oudenhove L, Gevers A, Janssens J. A controlled cross-over study of the selective serotonin reuptake inhibitor citalopram in irritable bowel syndrome. Gut. 2006;55:1095-103.

33. Talley NJ. Serotoninergic neuroenteric modulators. Lancet. 2001;358:2061-8.

34. Talley NJ, Gabriel SE, Harmsen WS, Zinsmeister AR, Evans RW. Medical costs in community subjects with irritable bowel syndrome. Gastroenterology. 1995; 109:1736-1741.

35. Tang YR, Yang WW, Wang YL, Lin L. Sex differences in the symptoms and psychological factors that influence quality of life in patients with irritable bowel syndrome. Eur J Gastroenterol Hepatol. 2012;24:702-7.

36. Tietjen GE, Herial NA, Hardgrove J, Utley C, White L. Migraine comorbidity constellations. Headache. 2007:47:857-65.

37. Toner BB, Akman D. Gender role and irritable bowel syndrome: literature review and hypotesis. American Journal of Gastroenterology. 2000;95:11-16.

38. Van Orshoven NP, Andriesse GI, van Schelven LJ, Smout AJ, Akkermans LM, Oey PL. Subtle involvement of the parasympathetic nervous system in patients with irritable bowel syndrome. Clin Auton Res. 2006;16:33-9.

39. Vandvik PO, Wilhelmsen I, Ihlebaek C, Farup PG. Comorbidity of irritable bowe syndrome in general practice:a striking feature with clinical implications. Alimen Pharmacol Ther. 2004;20:1195-203.

40. Warnock JK, Clayton AH. Chronic episodic disorders in women. Psychiatr Clin North Am. 2003;26:725-740.

41. Whitehead WE, Palsson O, Jones KR. Systematic reviewof the comorbidity of irritable bowel syndrome withother disorders: what are the causes and implications? Gastroenterology. 2002;122:1140-56.

42. Zwart JA, Dyb G, Hagen K, Svebak S, Stovner LJ, HolmenJ. Analgesic overuse among subjects with headache, neck,and low-back pain. Neurology. 2004:62:1540-4. 